\title{
PENGARUH RADIASI GAMMA TERHADAP SIFAT MEKANIK UHMWPE UNTUK TIBIAL TRAY
}

\author{
The Effect of Gamma Radiation on The Mechanical Properties of UHMWPE for \\ Tibial Tray
}

\author{
Sulistioso Giat Sukaryo ${ }^{1}$, Nurul Laili Arifin ${ }^{2}$, Sudaryo ${ }^{2}$, Sudirman ${ }^{1,3}$ \\ ${ }^{1}$ Pusat Teknologi Bahan Industri Nuklir (PTBIN)-BATAN \\ Kawasan Puspiptek, Serpong 15314, Tangerang Selatan \\ ${ }^{2}$ Sekolah Tinggi Teknologi Nuklir (STTN)-BATAN, Yogyakarta \\ ${ }^{3}$ Jurusan Kimia, FMIPA-UI,Kampus UI Baru, Depok \\ E-mail: sulistioso@gmail.com
}

Received 17 September 2012; revised 21 September 2012; accepted 23 Oktober 2012

\begin{abstract}
ABSTRAK
Dalam ortopedi UHMWPE sering digunakan sebagai bantalan materi (tibial tray) pada sendi lutut buatan. Namun dalam penggunaannya, keausan bahan UHMWPE merupakan salah satu faktor utama yang memperpendek umur pakai sendi lutut buatan sehingga diperlukan metode untuk meningkatkan sifat mekanik UHMWPE. Tujuan penelitian ini adalah untuk mengetahui pengaruh radiasi sinar gamma terhadap sifat mekanik dan tingkat keausan dari UHMWPE sehingga dapat memenuhi kualifikasi bahan baku pembuatan tibial tray serta mengetahui dosis optimum yang diperlukan UHMWPE agar diperoleh bahan yang tahan terhadap keausan dan memiliki sifat mekanik yang lebih baik. Pembuatan tibial tray dilakukan dengan metode molding pressure dengan radiasi gamma. Pembuatan film UHMWPE dilakukan dengan hot press pada $170{ }^{\circ} \mathrm{C}$ selama 3 menit dan tekanan $200 \mathrm{~kg} / \mathrm{cm}^{2}$. Kemudian film tersebut dipanaskan ke dalam furnace pada $128^{\circ} \mathrm{C}$ selama 100 menit dan diradiasi dengan irradiator karet alam (IRKA) pada dosis 0 kGy, 50 kGy, 100 kGy, 125 kGy dan 150 kGy. Berdasarkan hasil karakterisasi sifat tibial tray dengan $X R D, F T$-IR, alat uji tarik, alat uji kekerasan, dan alat uji keausan, dapat disimpulkan bahwa efek radiasi terhadap polimer UHMWPE adalah terbentuknya ikatan silang dan degradasi bahan. Sehingga, semakin tinggi dosis radiasi dihasilkan sifat bahan yang semakin keras serta tahan terhadap aus. Selain itu, dapat diketahui bahwa dosis 100 kGy merupakan dosis optimal untuk meningkatkan sifat mekanik bahan
\end{abstract}

Kata kunci : UHMWPE, Tibial tray, Hot press, Radiasi gamma, Ikatan silang, Degradasi, Dosis radiasi.

\begin{abstract}
Orthopedic UHMWPE is as often used bearing material (tibial tray) on the artificial knee joint. However, wearing and tearing of UHMWPE material is one of the major factors that shorten the life of an artificial knee joint as the necessary methods to improve the mechanical properties of UHMWPE. This study aims to determine the effect of gamma radiation on the mechanical properties and the wearing rate of UHMWPE determine the qualifications of tbial tray raw material as well as optimum dose required to obtain the wearing and tearing-resistant material with a good mechanical properties UHMWPE films was prepared by hot press at a $170{ }^{\circ} \mathrm{C}$ for 3 minutes and a pressure of $200 \mathrm{~kg} / \mathrm{cm}^{2}$ Film was then heated in a furnace at $128{ }^{\circ} \mathrm{C}$ for 100 minutes and irradiated with natural rubber irradiator (IRKA) at doses of 0 kGy, $50 \mathrm{kGy}, 100 \mathrm{kGy}, 125 \mathrm{kGy}$, and $150 \mathrm{kGy}$. Based on the characterization of tibial tray properties by XRD, FT-IR, tensile tester, hardness tester, and wear tester was concluded that the effects of radiation on UHMWPE polymer is structural crosslinking and degradation of materials. The higher dose of radiation results in the harder and wearing-resistant material. In addition, the optimum dose (100 kGy) improved the mechanical properties of materials.
\end{abstract}

Key words : UHMWPE, Tibial tray, Hotpress, Gamma radiation, Crosslinking, Degradation, Radiation dose.

\section{PENDAHULUAN}

Ultra-High Molecular Weight Polyethylene (UHMWPE) merupakan polimer yang stabil terhadap bahan kimia, tahan terhadap abrasi

dan penyobekan. Sejak tahun 1970, UHMWPE juga telah digunakan dalam ortopedi sebagai bantalan (tibial tray) pada sendi lutut buatan. 
Namun, dalam penggunaannya, keausan yang disebabkan oleh pengaruh gesekan material UHMWPE merupakan salah satu faktor utama yang memperpendek umur pakai sendi lutut buatan (Fang, Hsu and Sengers 2003).

Telah banyak penelitian yang melaporkan bahwa pembuatan tibial tray dari Ultra High Molecular Weight Polyethylene (UHMWPE) dengan memodifikasi sehingga dapat meningkatkan ketahanan mekaniknya, diantaranya pemanasan dengan iradiasi sinar gamma, radiasi berkas elektron (electron beam) (McKellop, et al. 1999), serta metode molding pressure tanpa iradiasi (Wang and Ge 2007). Metode molding pressure memiliki beberapa keuntungan, antara lain: Metode ini tidak membutuhkan tambahan mesin pencetak seperti pada proses pembuatan UHMWPE secara konvensional (Steven 2003).

Pemberian suhu di atas titik leleh UHMWPE pada $\left(\mathrm{T}_{\text {alat }}=170{ }^{\circ} \mathrm{C}\right)$, dapat menurunkan titik viskositas pelelehan (melt viscocity) UHMWPE sehingga dapat meningkatkan pergerakan rantai polimer, meningkatkan kekerasan dalam UHMWPE dan memudahkan proses pencetakan UHMWPE (Wang and Ge 2007; Steven 2003). Pemberian tekanan (sebesar $200 \mathrm{~kg} / \mathrm{cm}^{2}$ ) pada metode ini, menyebabkan pemanasan menjadi merata ke seluruh bagian UHMWPE sehingga dapat mengurangi adanya gelembung udara yang terjebak (Retno 2011).

Pada metode iradiasi dapat menghasilkan radikal bebas yang dapat menyebabkan pembentukan ikatan silang (crosslinking) dan pemecah rantai (degradasi) polimer antara molekul polietilen yang berdekatan. Pembentukan ikatan silang dapat digunakan untuk meningkatkan kinerja penggunaan Polietilen (PE). Laboratorium hip simulator telah melakukan tes pakai dan menunjukkan bahwa ada penurunan tingkat keausan dengan adanya peningkatan derajat crosslinked PE (Steven 2003).

Ikatan silang dapat dilakukan melalui iradiasi sinar gamma, yang pada umumnya bersumber dari kobalt (Co-60), dengan penetrasi ke UHMWPE yang tidak terbatas. Dosis radiasi merupakan salah satu variabel yang dapat mempengaruhi sifat mekanik polimer. Dengan peningkatan dosis radiasi (D), maka terjadi penurunan tingkat keausan secara signifikan pada dosis $100 \mathrm{kGy}$ hingga $150 \mathrm{kGy}$, dan terus mengalami penurunan hingga batas tertentu (Lewis 2001) Kekerasan UHMWPE semakin meningkat seiring bertambahnya dosis radiasi pada kisaran 0 kGy hingga 500 kGy dengan nilai kekerasan 64-68 shore (Rosario and Silva 2006).
Selain itu, hasil pengujian menunjukkan bahwa tingkat keausan metode Slab Compression Molded (SCM) dengan iradiasi polimer (60 kGy) adalah sekitar 63\% lebih rendah dari metode SCM standar (30 kGy) (John, Kenneth and Poggie 2003). Hal ini menandakan bahwa melalui cara iradiasi, dapat meningkatkan sifat mekanik dan kimia material (Abt, et al. 2003). Namun, J-integral (ukuran ketangguhan patah) akan mengalami penurunan seiring dengan meningkatnya dosis, sehingga hal ini membuat situasi yang tidak diinginkan. Keterkaitan antara dosis serap radiasi terhadap sehat mekanik UHMWPE menunjukkan hubungan yang paradoksial serta ketergantungan sigmoidal yang perlu diteliti.

\section{BAHAN DAN METODE}

\section{Bahan}

Bahan yang digunakan serbuk Ultra High Molecular Weight Polyethylene (UHMWPE) dengan berat molekul sebesar (3-6 juta) $\mathrm{g} / \mathrm{mol}$ merek Sigma-Aldrich USA, alumunium foil dan kertas transparansi.

Alat yang digunakan meliputi : iradiator, cetakan plat berbentuk kotak dengan ukuran (20 x 20) $\mathrm{cm}^{2}$, alat tekan panas (hotpress-hydraulics type = pj16h; kapasitas $=16$ ton dan No.serial = 39326) dan alat tekan dingin (coldpress). Peralatan uji keausan meliputi: pengaus (terbuat dari alumina ), beban pengaus, dan holder sampel. Alat pencetak dumbell, mikrometer sekrup, Peralatan uji sifat mekanik merek Toyoseiki, Hardness tester (Zwick ISO/R 868), Furnace, gunting, alat $F T$-IR dan alat $X R D$ merek Shimadzu Difractometer XD-610.

\section{Metode}

\section{Pembuatan Film UHMWPE}

Cetakan plat berbentuk persegi ukuran $(20 \times 20) \mathrm{cm}^{2}$ dengan dan tebal $0,5 \mathrm{~mm}$ diisi serbuk UHMWPE sebanyak 12 gram. Kemudian dikompaksi pada suhu $170{ }^{\circ} \mathrm{C}$ pada tekanan sebesar $200 \mathrm{~kg} / \mathrm{cm}^{2}$ dan ditahan selama 3 menit. Setelah itu, sampel dikeluarkan dari alat tekan panas (hotpress) dan dimasukkan ke dalam alat tekan dingin (coldpress) selama 10 menit kemudian dikeluarkan dari cetakan. Hasil dari proses ini, berupa film UHMWPE berbentuk persegi ukuran $(20 \times 20) \mathrm{cm}^{2}$ dengan ketebalan $0,5 \mathrm{~mm}$.

\section{Pembuatan Sampel Tibial Tray}

Film UHMWPE dipotong berbentuk lingkaran dengan diameter $35 \mathrm{~mm}$ sebanyak 12 buah. Hasil potongan film tersebut dijadikan satu dan dilapisi dengan alumunium foil. 
Selanjutnya potongan film tersebut dipanaskan ke dalam furnace dengan suhu $128{ }^{\circ} \mathrm{C}$ selama 100 menit.

\section{Iradiasi UHMWPE dengan Sinar Gamma}

Sampel dimasukkan ke dalam ampul kemudian diiradiasi dengan sinar gamma $(\mathrm{Y})$ menggunakan sumber yang berasal dari radioisotop $\mathrm{Co}^{60}$. Iradiasi dilakukan dengan alat Iradiator Karet Alam (IRKA) dengan dosis 50 kGy, 100 kGy, 125 kGy, dan 150 kGy pada laju dosis $9,9 \mathrm{kGy} / \mathrm{jam}$. Sampel yang diradiasi berbentuk film uji tarik sesuai ASTM D1822L dan film UHMWPE yang telah dibentuk tibial tray.

\section{Karakterisasi}

\section{a. Kekerasan}

Uji kekerasan dilakukan dengan cara sampel diukur ketebalannya (tebal minimal 6 $\mathrm{mm}$ ). Sampel diletakkan pada tempat yang rata kemudian dilakukan uji kekerasan dengan alat uji keras shore A untuk $1 \mathrm{~kg}$. Setiap uji dilakukan selama 15 detik, skala uji kekerasan shore A berkisar antara 0 hingga 100 . Pengukuran dilakukan sebanyak tiga kali ulangan. Nilai kekerasan shore A dikonversi ke dalam shore (Retno 2011).

\section{b. Keausan}

Film UHMWPE dipotong dengan ukuran $(10 \times 20) \mathrm{mm}^{2}$ dan tebal $2 \mathrm{~mm}$. Kemudian, sampel UHMWPE ditimbang beratnya. Setelah itu, sampel yang akan diuji dimasukkan ke dalam holder, diberi beban gesek dan digesekkan pada permukaan pengaus dengan waktu, beban dan kecepatan pengausan yang telah ditentukan. Hasil penggesekan bahan ini pengurangan massa bahan akibat kontak antar permukaan. Penentuan tingkat keausan pada bahan berdasarkan volume keausan material. Semakin besar volume keausan maka semakin tinggi bahan yang terlepas dari sampel. Besarnya volume keausan sampel dapat ditentukan dengan Persamaan (1)

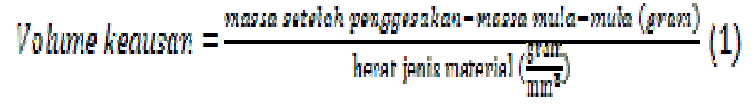

\section{c. Kekuatan Tarik}

Film UHMWPE diukur kekuatan tariknya dengan alat uji kekuatan tarik (Tensile Strength). Film UHMWPE dicetak di alat pencetak dumbel sehingga berbentuk dog bone yang sesuai standar ASTM D1822L. Dumbell memiliki ukuran panjang $($ Lo $)=69 \mathrm{~mm}$, lebar sebesar $(\mathrm{Wo})=10$ $\mathrm{mm}$, lebar bagian tengah sebesar $(\mathrm{Wc})=3 \mathrm{~mm}$ dengan panjang $(\mathrm{D})=27 \mathrm{~mm}$, seperti diperlihatkan pada Gambar 1.

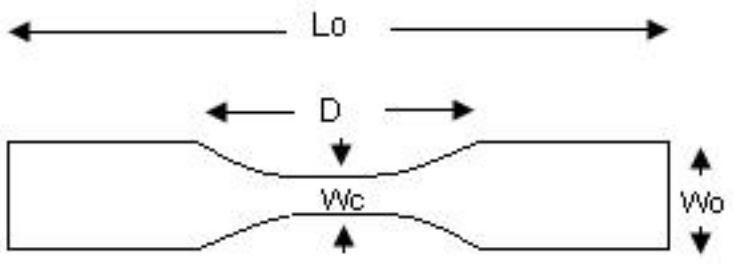

Gambar 1. Spesimen Dumbell ASTM D 1822 L

Film diukur ketebalannya terlebih dahulu dengan mikrometer sekrup. Setelah itu, film dijepit diantara kedua pendulum dalam alat Toyoseiki. Sampel ditarik sampai putus dengan kecepatan konstan $100 \mathrm{~mm} /$ menit sehingga dapat diketahui besarnya gaya maksimum dan persen perpanjangan putus sampel saat putus. Pengukuran dilakukan sebanyak lima kali ulangan (Retno 2011).

\section{d. Penentuan Derajat Kristalinitas}

Pengukuran derajat kristalinitas dengan $X R D$, dilakukan dengan cara sampel UHMWPE ukuran tertentu $( \pm 2 \times 2) \mathrm{cm}^{2}$ ditempelkan pada spesimen holder dengan perekat ganda yang kemudian diletakkan pada goniometer dan

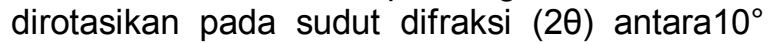
hingga $30^{\circ}$. Polimer UHMWPE merupakan jenis polimer semikristalin sehingga ada dua jenis puncak yang terlihat dalam difraktogram hasil $X R D$, yaitu puncak yang tajam dan puncak yang lebar. Puncak yang tajam adalah daerah kristalin, sedangkan puncak yang lebar adalah daerah amorf. Derajat kristalinitas sampel dapat ditentukan melalui difraktogram hasil XRD berdasarkan luasan puncak tersebut dengan menggunakan Persamaan (2) (Retno 2011):

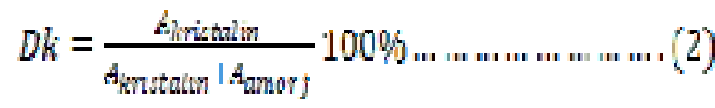

Dimana:

Dk = Derajat kristalinitas $(\%)$

$A_{\text {kristalin }}=$ Luas daerah kristalin $\left(\mathrm{cm}^{2}\right)$

$\mathrm{A}_{\mathrm{amorf}}=$ Luas daerah amorf $\left(\mathrm{cm}^{2}\right)$

\section{Penentuan Gugus Fungsi}

Analisis sampel dilakukan dengan cara UHMWPE dalam bentuk film dikarakterisasi dengan spektroskopi $F T$-IR. Pengujian dilakukan pada bilangan gelombang $4000 \mathrm{~cm}^{-1}$ hingga 400 $\mathrm{cm}^{-1}$. Estimasi Indexs Oksidasi Total $\left(\mathrm{I}_{\mathrm{ox}}\right)$ sesuai ISO 5834-4, dilakukan dengan cara analisis 
spektrum FT-IR pada daerah $1200 \mathrm{~cm}^{-1}$ hingga $2000 \mathrm{~cm}^{-1}$ dan peak tertinggi di rentang daerah tersebut (dalam hal ini dipilih pada peak $\left.1365 \mathrm{~cm}^{-1}\right)$. Kemudian dicari dan dicatat \%transmitan peak pada daerah dengan tingkat oksidasi tertinggi (berdasarkan literatur pada rentang $1650 \mathrm{~cm}^{-1}$ hingga $1850 \mathrm{~cm}^{-1}$ ). Sesuai dengan ISO 5834-4, persamaan yang digunakan adalah Persamaan (3) (Magda, Alexandra, and Herman 2009)

Total Oxidation Indexs (IOx) $=\frac{A_{\mathrm{Q}}}{A_{R}}=\frac{A_{(1050-1300)}}{A_{(1200-2000)}}$

Sedangkan untuk penentuan trans-vinilen index dianalisis dengan cara dilakukan pengamatan keberadaan gugus fungsi transvinilen $\left(-\mathrm{CH}=\mathrm{CH}_{2}\right)$ yang terdapat pada spektrum FT-IR sebelum dan setelah iradiasi gamma. Berdasarkan referensi, gugus fungsi trans-vinilen terdapat pada daerah bilangan gelombang $800 \mathrm{~cm}^{-1}$ hingga $1000 \mathrm{~cm}^{-1}$ (Greer, King and Chan 2003).

\section{HASIL DAN PEMBAHASAN}

Berdasarkan pengamatan secara visual, efek penyerapan sinar gamma pada dosis tinggi terhadap materi (UHMWPE) adalah terjadinya perubahan warna tibial (seperti yang diperlihatkan pada Gambar 2).
Pada dosis 125 kGy hingga 150 kGy, tibial berubah warna dari putih menjadi putih buram. Adanya perubahan warna pada polimer menunjukkan bahwa untuk dosis tersebut polimer telah mengalami degradasi. Peristiwa degradasi diakibatkan oleh Co- ${ }^{60}$ yang memancarkan sinar gamma berenergi rata-rata $1250 \mathrm{MeV}$. Karena $\mathrm{E}_{\mathrm{\gamma}}>\mathrm{E}_{\text {pemutus ikatan }}$ (Energi pemutus 1 ikatan adalah $\pm 20 \mathrm{eV}$ ), artinya efek radiasi tersebut dapat mengakibatkan terjadinya pemutusan ikatan (Basuki 2000).

Akibat pemutusan ikatan berakibat terbentuknya radikal polimer. Radikal polimer (R.) dengan oksigen dapat bereaksi dengan mudah membentuk radikal peroksi polimer (ROO) (Wiwik, Subono and Rahmat 1994). Kemudian, radikal bebas peroksi bereaksi dengan hidrogen dan membentuk hidroperoksida yang tidak stabil dan menurunkan produk menjadi oksidasi, terutama keton dan ester (Wang and Ge 2007). Keberadaan produk tersebut dapat dibuktikan melalui spektrum FTIR hasil iradiasi UHMWPE pada dosis $125 \mathrm{kGy}$ hingga 150 kGy.

Produk oksidasi hasil iradiasi sinar gamma berupa spesies karbonil yang terletak pada bilangan gelombang $1710 \mathrm{~cm}^{-1}$ hingga $1740 \mathrm{~cm}^{-1}$. Hidroperoksida dan alkohol pada $3450 \mathrm{~cm}^{-1}$ hingga $3350 \mathrm{~cm}^{-1}$ sedangkan eter dan kelompok -C-O-C- terletak pada bilangan gelombang $1100 \mathrm{~cm}^{-1}$ hngga $1400 \mathrm{~cm}^{-1}$ (Magda, Alexandra, and Herman 2009).
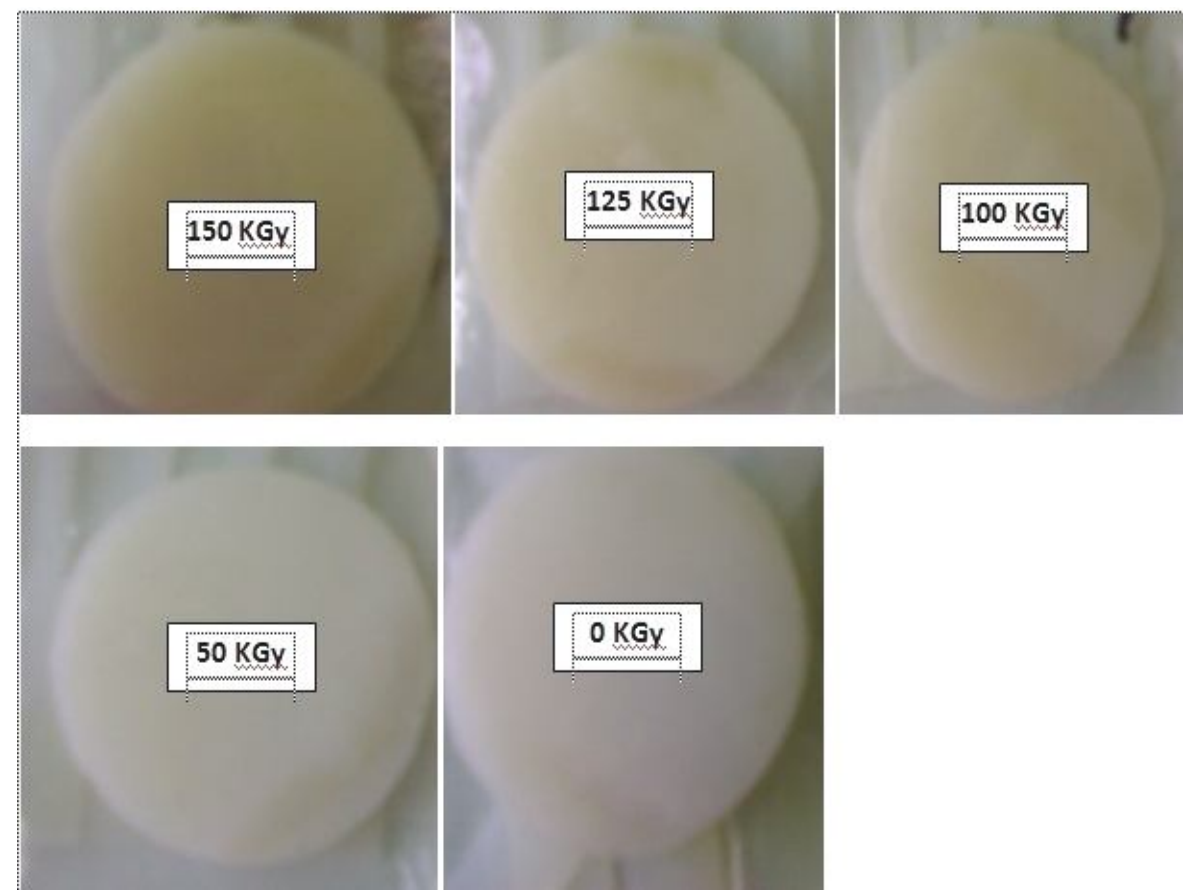

Gambar 2. Perubahan warna tibial polimer UHMWPE 
Gambar 3 memperlihatkan spekturm FT-IR dari gugus fungsi oksidasi dari hasil iradiasi UHMWPE. Apabila besarnya tingkat oksidasi dari Indexs Oksidasi Total $\left(\mathrm{I}_{\mathrm{ox}}\right)$ dilakukan perhitungan secara kuantitatif berdasarkan ISO 5834-4 maka didapatkan bahwa untuk dosis 125 kGy dan 150 kGy adalah 3,66 dan 4,13.

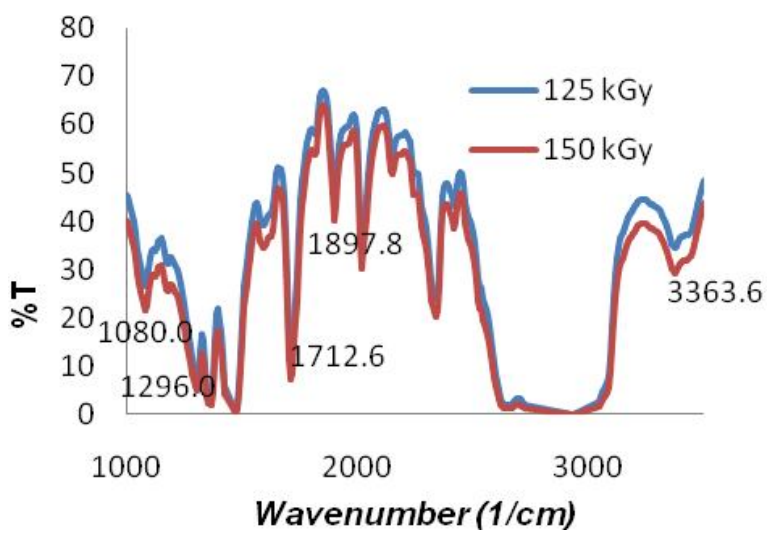

Gambar 3. Spektrum F-IR dari hasil oksidasi UHMWPE.

\section{Pengaruh Dosis Radiasi Gamma Terhadap Kekerasan dan Derajat Kristalinitas UHMWPE}

\section{a. Kekerasan Bahan}

Radiasi sinar-y dapat mempengaruhi kekerasan polimer UHMWPE. Berdasarkan hasil pengujian kekerasan, dapat diketahui bahwa besarnya dosis radiasi berbanding lurus terhadap nilai kekerasan polimer UHMWPE (Shore A) diperlihatkan pada Gambar 4.

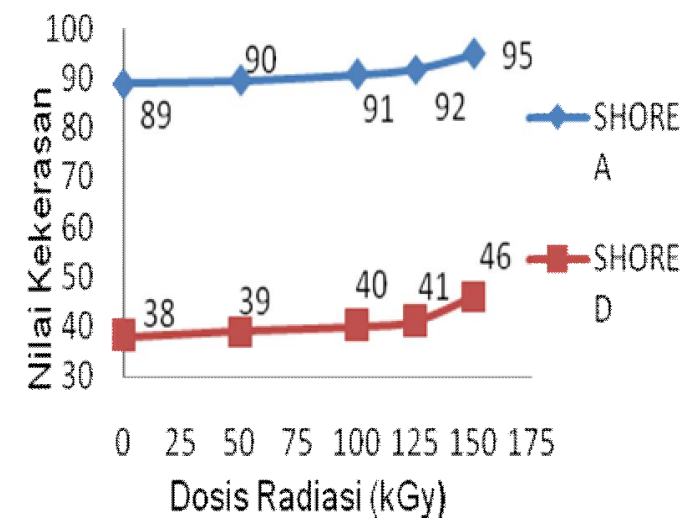

Gambar 4. Hubungan dosis radiasi terhadap nilai kekerasan
Selain itu, berdasarkan hasil pengukuran terdahulu diketahui bahwa nilai kekerasan polimer UHMWPE terletak pada kisaran 38 - 46 (shore D) dan nilai kekerasan terbesar terjadi pada dosis 150 kGy yaitu 46 (shore D) dengan peningkatan kekerasan sebesar $21 \%$. Nilai tersebut mendekati hasil penelitian sebelumnya yang menyatakan bahwa nilai kekerasan UHMWPE semakin tinggi seiring bertambahnya dosis iradiasi dan berada pada kisaran $(45,36$ $46,39)$ shore $D$.

Terjadinya peningkatan kekerasan bahan seiring meningkatnya dosis dapat dikarenakan beberapa faktor. Semakin tinggi dosis iradiasi, maka semakin banyak radikal yang terjadi dan menyebabkan kenaikan jumlah reaksi terminasi antara ikatan rangkap pada rantai utama terhadap sisa rantai monomer yang masih aktif. Reaksi ini menghasilkan kenaikan jumlah ikatan silang. Semakin banyak rantai yang terbentuk setiap satuan waktu maka semakin banyak pula jumlah ikatan rantai yang terjadi dan selanjutnya meningkatkan kekerasan (Marsongko 1997).

Peristiwa terjadinya ikatan silang pada polimer UHMWPE hasil radiasi ditandai dengan keberadaan produk hasil ikatan silang yaitu kehadiran cis-vinilen dan trans-vinilen (dalam fasa amorf) dan trans-vinilen (dalam fasa kristalin) (Steven 2003). Pada spektrum FT-IR, keberadaan trans-vinilen terletak pada daerah bilangan gelombang $964,3372 \mathrm{~cm}^{-1}$.

Berdasarkan puncak spektrum FT-IR, diperoleh bahwa tinggi puncak UHMWPE pada dosis.150 kGy lebih tinggi daripada dosis 125 kGy. Sedangkan untuk film UHMWPE yang belum diradiasi ( $0 \mathrm{kGy}$ ), tidak menunjukkan adanya puncak FT-IR yang terbentuk. Hal ini berarti, ikatan silang yang terbentuk pada dosis 150 kGy lebih banyak daripada dosis 125 kGy, untuk dosis $0 \mathrm{kGy}$, belum terbentuk ikatan silang. Hal ini seperti diperlihatkan pada Gambar 5.

Pengaruh dosis radiasi terhadap kekerasan polimer UHMWPE ditandai dengan tingkat kristalinitas bahan. Kristalinitas sangat berguna bagi polimer. Semakin meningkat kristalinitas suatu polimer, maka polimer tersebut memiliki ketahanan terhadap pelarut dan membuat polimer menjadi kaku dan lebih kuat

\section{b. Kristalinitas Bahan}

Kristalinitas suatu polimer dapat dinyatakan melalui derajat kristalinitas. Hanya polimer yang mempunyai fasa semi kristalin yang dapat ditentukan harga derajat kristalinitasnya (Sudirman 1994). Polimer UHMWPE merupakan polimer yang bersifat semi kristalan. Hal ini ditunjukan dari hasil pengukuran dengan $X R D$ 


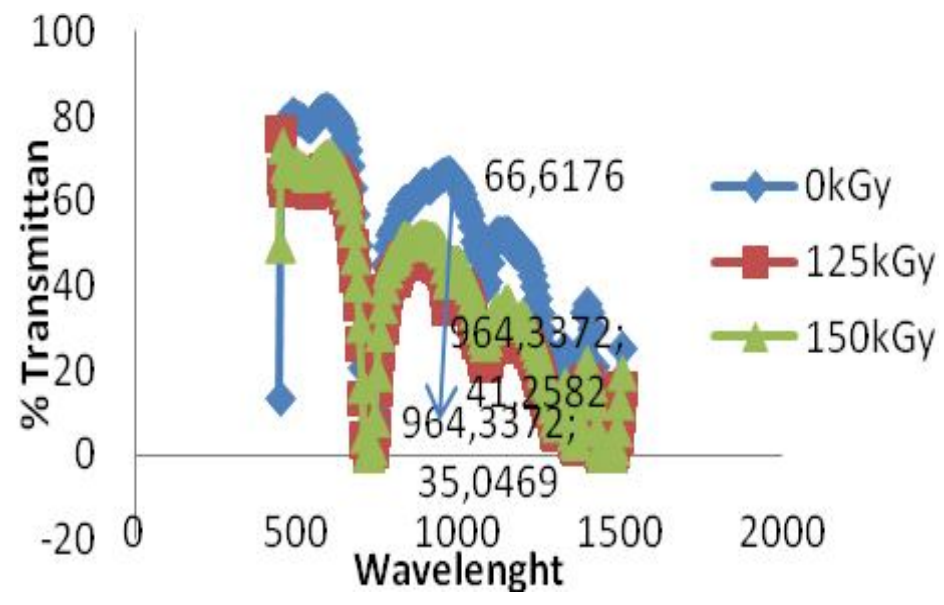

Gambar 5. Spektrum FT-IR dari trans-vinilen

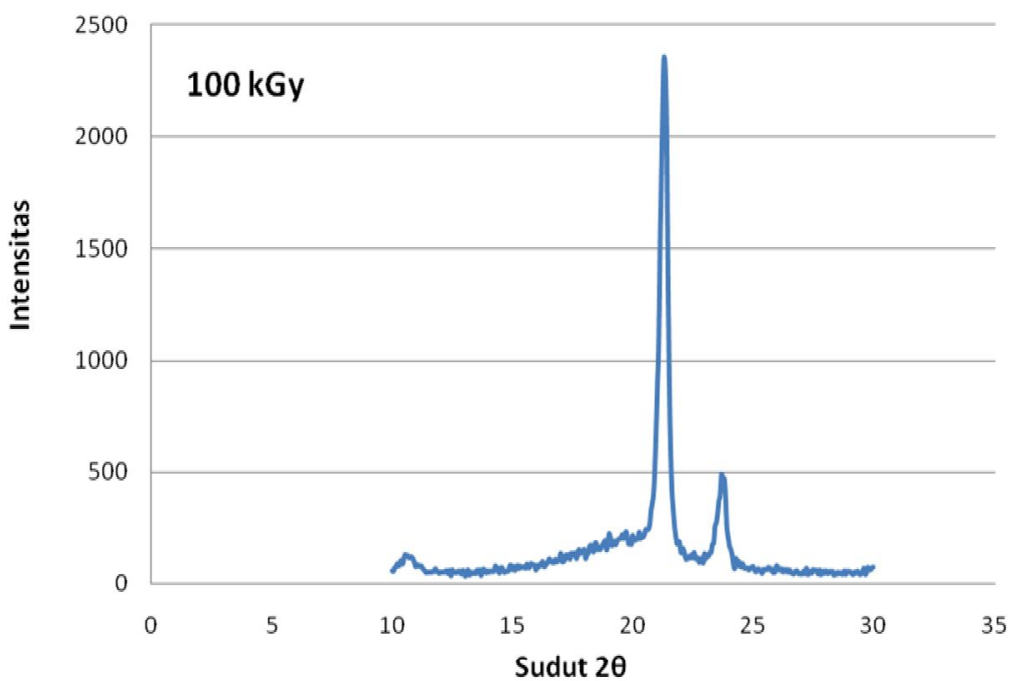

Gambar 6. Difaktogram XRD dari UHMWPE

Berdasarkan hasil pengamatan pada difaktogram UHMWPE, seperti yang ditunjukkan pada Gambar 6, memperlihatkan bahwa pada polimer UHMWPE diperoleh daerah amorf dan daerah kristalin.

Gambar 7 memperlihatkan hubungan dosis radiasi dengan derajat kristalinitas dari UHMWPE dengan dosis 0 kGy hingga-100 kGy. Dari Gambar 7 tersebut menunjukkan bahwa terjadi peningkatan derajat kristalinitas tertinggi terletak pada dosis $100 \mathrm{kGy}$ yaitu sebesar $7,89 \%$. Hasil ini sesuai dengan penelitian sebelumnya (Kim and Nho 2009) bahwa semakin tinggi dosis radiasi, maka semakin tinggi derajat kristalinitasnya. Namun, peningkatan derajat kristalinitas pada dosis tersebut tidak terjadi secara signifikan, artinya peningkatan kekerasan bahan hanya meningkat

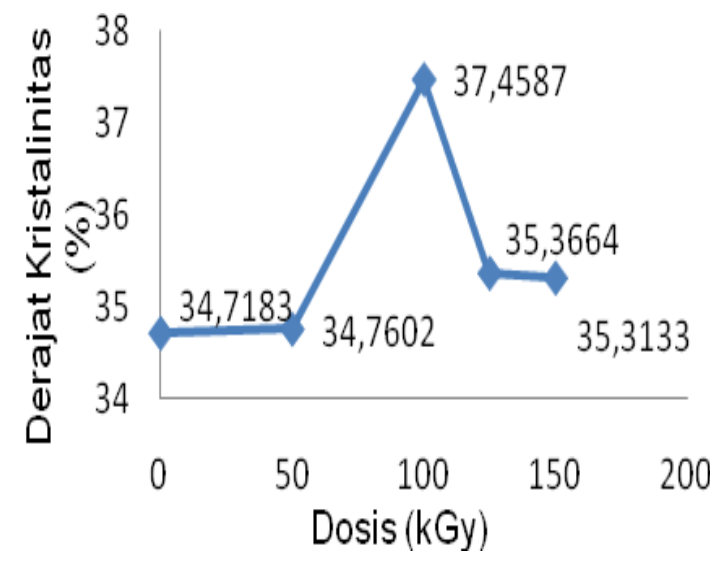

Gambar 7. Hubungan dosis dadiasi (kGy) terhadap derajat kristalinitas UHMWPE 
Sedangkan untuk dosis 125 kGy hingga150 kGy memperlihatkan kristalinitas UHMWPE mengalami penurunan. Penurunan derajat kristalinitas dikarenakan terjadinya degradasi. Proses degradasi melalui oksidasi mengakibatkan terjadinya migrasi radikal dari fasa kristalin ke bagian permukaan amorf (Suliwarno 1997)

Namun, penurunan derajat kristalinitas bahan pada dosis 125 kGy hingga 150 kGy tidak berpengaruh terhadap kekerasan bahan. Hal ini dikarenakan, penurunan derajat kristalinitas pada dosis tersebut sangat kecil yaitu $0,15 \%$ hingga $5,6 \%$ dari dosis semula.

\section{Pengaruh Radiasi terhadap Hasil Uji Tarik}

Berdasarkan hasil pengukuran, nilai modulus elastisitas polimer UHMWPE yang telah diradiasi pada dosis 0 kGy hingga 150 kGy terletak pada jangkauan 28,052 MPa hingga 142,203 MPa dan dari hasil uji tarik diketahui bahwa semakin tinggi dosis maka semakin besar modulus elastisitas suatu polimer UHMWPE. Modulus elastisitas yang meningkat diakibatkan oleh laju tegangan yang tinggi. Sehingga renggangannya mengecil dan bahan mudah patah (Suliwarno 1997). Selain itu, modulus dari polimer semikristal dipengaruhi oleh derajat kristalinitas polimer. Nilai modulus elastisitas berbanding lurus dengan derajat kristalinitas.

Selain itu, kenaikan dosis juga berdampak pada tegangan dan \% perpanjangan putus polimer UHMWPE. Semakin tinggi dosis nilai tegangan luluh polimer UHMWPE dan \% perpanjangan putus bahan mengalami penurunan. Kenaikan dosis iradiasi menurunkan perpanjangan putus bahan diakibatkan adanya kenaikan jumlah ikatan silang.

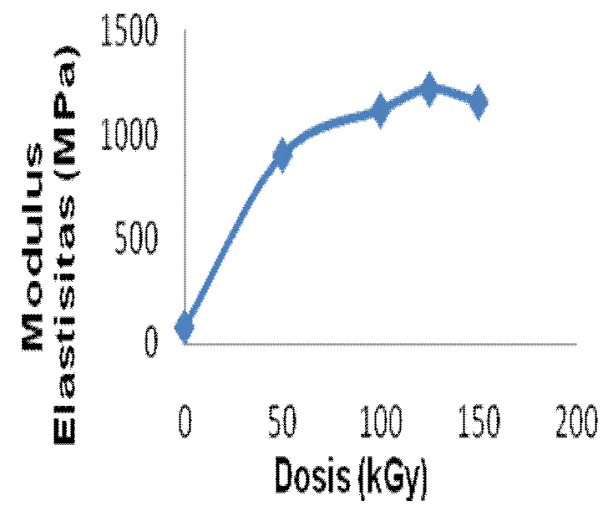

Gambar 8. Hubungan dosis radiasi terhadap modulus elastisitas
Jika film ditarik/direnggangkan, rantai polimer yang tidak berikatan silang relatif mudah bergerak satu terhadap yang yang lain sehingga menghasilkan renggangan yang tinggi sebelum putus. Apabila jumlah ikatan silang antara rantairantai polimer ini meningkat, rantai polimer menjadi tidak mudah bergerak satu dengan yang lain, sehingga nilai perpanjangan putusnya mengalami penurunan (Wiwik, Subono,and Rahmat. 1994).

Tegangan luluh bahan hasil pengujian tarik terletak pada kisaran $29 \mathrm{MPa}$ hingga 41 MPa. Nilai tersebut sesuai dengan ISO 5834-2 (standar produk untuk implant) sebesar > 19 MPa. Nilai tegangan maksimum dan \% perpanjangan putus hasil radiasi diperlihatkan pada Gambar 9 dan Gambar 10.

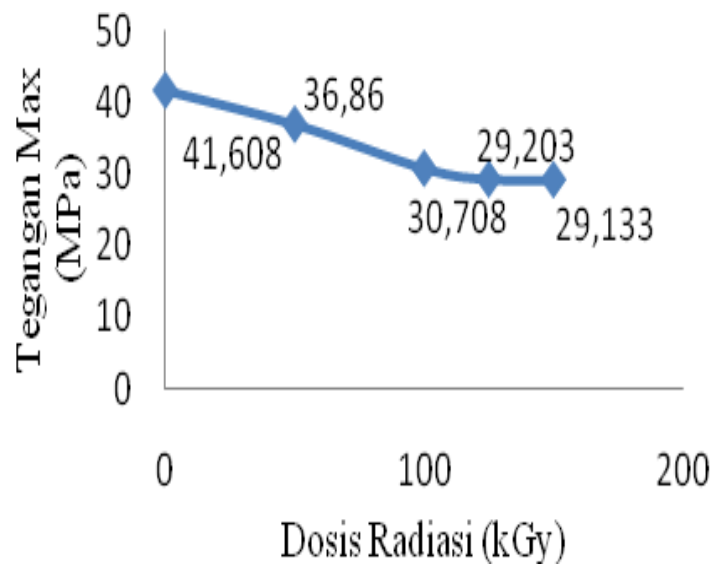

Gambar 9. Hubungan dosis radiasi (kGy) terhadap tegangan maksimum (MPa)

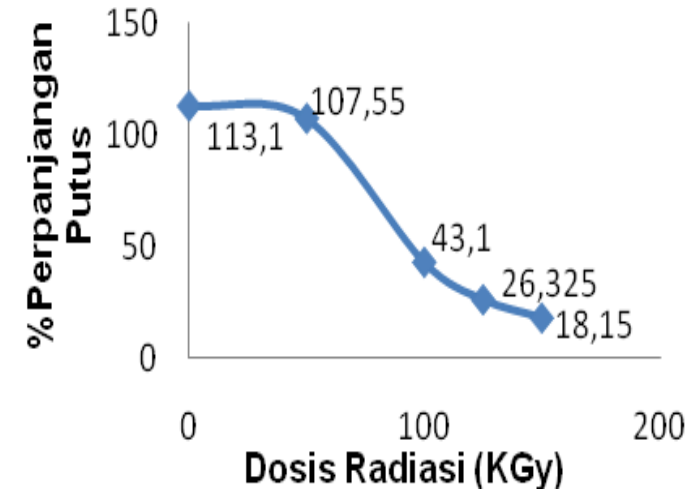

Gambar 10. Hubungan dosis radiasi (kGy) terhadap $\%$ perpanjangan putus. 


\section{Pengaruh Radiasi terhadap Keausan UHMWPE}

Berdasarkan hasil uji keausan yang tertera pada Gambar 11 menunjukkan bahwa semakin tinggi dosis maka semakin meningkat ketahanan bahan terhadap terjadinya keausan (akibat perilaku mekanik). Dalam hal ini ketahanan aus ditandai dengan volume keausan bahan yang terlupas semakin menurun saat dilakukan penggesekan. Nilai penurunan volume keausan terbesar terjadi pada dosis $125 \mathrm{kGy}$ sebesar $28,11 \%$. Sedangkan untuk dosis $50 \mathrm{kGy}$ dan $100 \mathrm{kGy}$, peningkatan ketahanan aus sebesar $11,1 \%$ dan $22,21 \%$.

Permukaan yang keras dan licin akan meningkatkan ketahanan aus UHMWPE. Secara kualitatif, hasil uji keausan diamati morfolgi permukaannya dengan mikroskop optik. Berdasarkan hasil pengamatan, yang tertera pada Gambar 12, kerusakan terparah terjadi pada dosis $0 \mathrm{kGy}$. Pada dosis tersebut bahan tibial tray mengalami pengelupasan dan terdapat goresan di permukaannya. Pengelupasan inilah, yang dinamakan delaminasi sedangkan goresan pada permukaan dinamakan abrasi. Sedangkan untuk dosis $50 \mathrm{kGy}$ hingga $125 \mathrm{kGy}$, jumlah goresan bahan pada permukaan semakin berkurang.

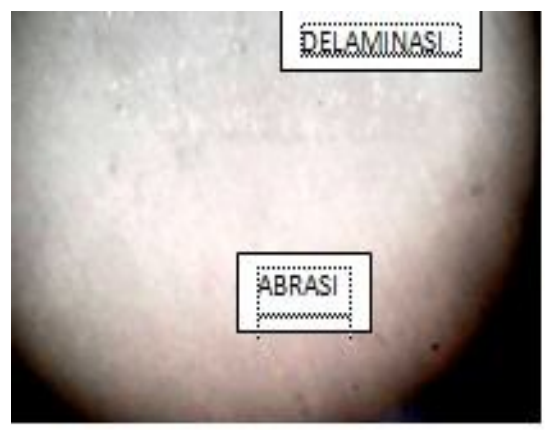

(a)

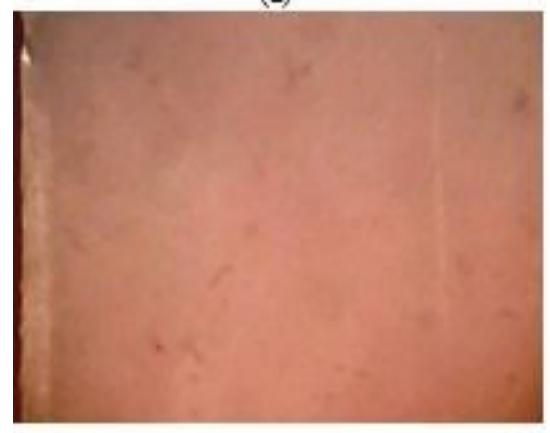

(c)
Terjadinya pengelupasan dan goresan pada bahan diakibatkan oleh adanya keausan adhesif (Adhesive wear) yaitu keausan yang terjadi akibat kontak permukaan antara UHMWPE dengan bahan penggesek (alumina). Kemudian, interaksi ini mengakibatkan proses adhesif dan mengakibatkan terjadinya pelepasan bahan UHMWPE (ditandai dengan terjadinya pengurangan massa bahan).

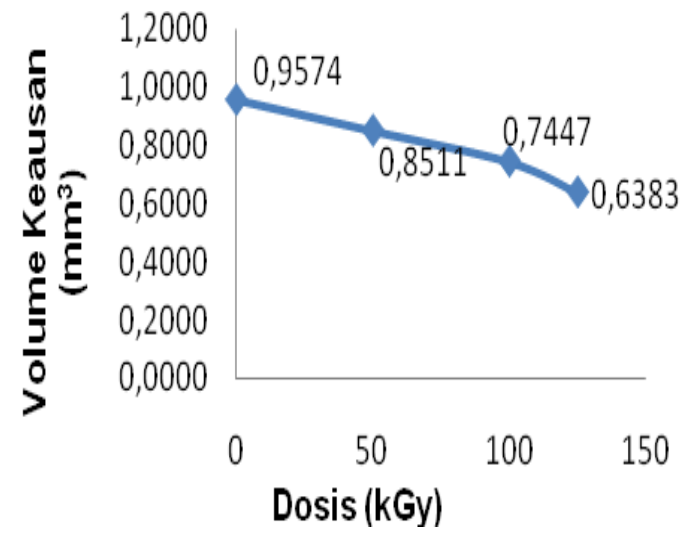

Gambar 11. Hubungan dosis radiasi (kGy) terhadap volume keausan $\times 10^{-03}\left(\mathrm{~cm}^{3}\right)$

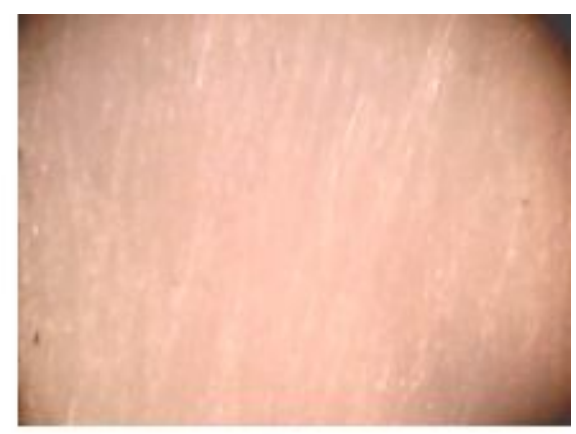

(b)

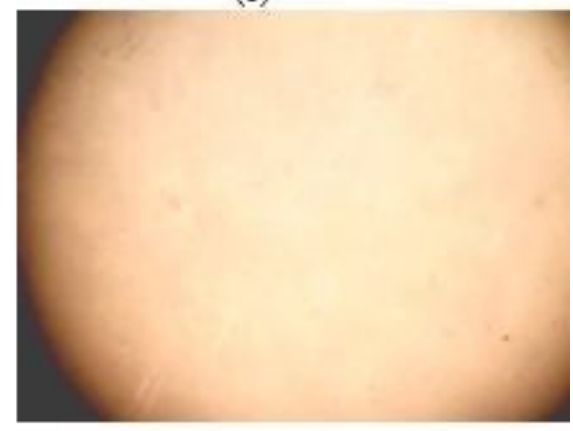

(d)

Gambar 12. Hasil uji aus tibial tray pada dosis : (a). 0 kGy, (b) 50 kGy (c) 100 kGy dan (d) 125 kGy. 
Tabel 1. Sifat mekanik dari HDPE dan UHMWPE

\begin{tabular}{lcc}
\hline \multicolumn{1}{c}{ Property } & HDPE & UHMWPE \\
\hline Tensile Modulus of Elasticity (GPa) & $0,4-4,0$ & $0,8-1,6$ \\
Tensile Yield Strength $\left(\mathbf{N} / \mathbf{m m}^{2}\right)$ & $26-33$ & $21-28$ \\
Tensile Ultimate Strength $\left(\mathbf{N} / \mathbf{m m}^{2}\right)$ & $22-31$ & $39-48$ \\
Tensile Ultimate Elongation $\left(\mathbf{N} / \mathbf{m m}^{2}\right)$ & $10-1200$ & $350-525$ \\
Degree of Crystallinity $(\%)$ & $60-80$ & $39-75$ \\
\hline
\end{tabular}

Tabel 2. Hasil pengujian terhadap Tibial Tray UHMWPE

\begin{tabular}{ccccccc}
\hline No. & $\begin{array}{c}\text { Dosis } \\
\text { (kGy) }\end{array}$ & $\begin{array}{c}\text { Tegangan } \\
\text { Luluh } \\
\text { (MPa) }\end{array}$ & $\begin{array}{c}\text { Kekerasan } \\
\text { (Shore A) }\end{array}$ & $\begin{array}{c}\text { \%perpanjangan } \\
\text { Putus }\end{array}$ & $\begin{array}{c}\text { Derajat } \\
\text { Kristalinitas } \\
(\%)\end{array}$ & $\begin{array}{c}\text { Volume } \\
\text { Keausan } \mathbf{x} \mathbf{1 0}^{-3} \\
\mathbf{( c m}^{\mathbf{3}} \mathbf{\text { ( }}\end{array}$ \\
\hline 1. & 0 & 41,61 & 89 & 113,1 & 34,71 & 0,957 \\
2. & 50 & 36,86 & 90 & 107,55 & 34,76 & 0,851 \\
3. & 100 & 30,71 & 91 & 43,1 & 37,46 & 0,744 \\
4. & 125 & 29,2 & 92 & 26,32 & 35,37 & 0,688 \\
5. & 150 & 29,13 & 95 & 18,15 & 35,31 & - \\
\hline
\end{tabular}

\section{Penentuan Dosis Optimum}

Persyaratan bahan untuk tibial tray adalah keras, tahan aus, dan tidak getas. Pada penelitian ini hasil yang paling optimum didapat pada dosis $100 \mathrm{kGy}$. Pemilihan ini didasarkan pada hasil uji tarik, persentase peningkatan nilai kekerasan dan penurunan volume keausan bahan, namun \% perpanjangan putus. Dalam aplikasinya tibial tray akan bergesekan dengan knee cap yang terbuat dari paduan logam. Hasil keseluruhan pengujian terhadap tibial tray UHMWPE dapat dilihat pada Tabel1.

Dari Tabel 2, untuk dosis 50 kGy memperlihatkan kekerasan meningkat sebesar $1,12 \%$ dan ketahanan aus meningkat sebesar $11,1 \%$. Sedangkan tegangan luluh menurun sebesar $11,41 \%$. Sedangkan untuk dosis 100 kGy, menunjukkan bahwa kekerasan bahan meningkat sebesar 2,25\%, ketahanan aus meningkat sebesar $22,21 \%$ dan bahan berada pada rentang peningkatan derajat kristalinitas tertinggi sebesar $7,89 \%$. Pada dosis ini tegangan maksimum bahan turun sebesar $26,2 \%$ yang menyebabkan juga terjadinya penurunan elastisitas bahan. Namun, nilai tegangan maksimum pada dosis $100 \mathrm{kGy}$ telah memenuhi standar ISO 5834-2 (standar produk untuk implant) sebesar > $19 \mathrm{MPa}$.

Pada dosis 125 kGy hingga150 kGy, terjadi peningkatan kekerasan lebih tinggi dari dosis $100 \mathrm{kGy}$. Tapi pada kedua dosis ini, nilai persentase perpanjangan putus sudah sangat rendah atau dapat diartikan bahwa bahan sudah getas, dikarenakan oleh bahan telah mengalami degradasi. Selain itu, jika ditinjau dari aspek ekonomis, kedua dosis ini lebih membutuhkan biaya yang lebih mahal daripada dosis $100 \mathrm{kGy}$.

\section{KESIMPULAN}

Semakin tinggi dosis radiasi maka dapat dihasilkan sifat UHMWPE hasil hotpressing yang semakin keras dan tahan terhadap aus. Dosis optimum yang dipakai untuk meningkatkan sifat mekanik bahan terletak pada dosis $100 \mathrm{kGy}$. Pada dosis 125 kGy hingga150 kGy, terjadi persentase perpanjangan putus sudah sangat rendah atau dapat diartikan bahwa bahan sudah getas, dikarenakan oleh bahan telah mengalami degradasi

\section{DAFTAR PUSTAKA}

Abt, N. A., Schneider, W., Schon, R., dan Rieker, C. B., 2003. Crosslinked and Thermally Treated Ultra-High Molecular Weight Polyethylene for Joint Replacements, ASTMSTP 1445, S. M. Kurtz, R. Gsell, and J. Martell, Eds.p. 228-238, ASTM International, West Conshohocken, PA.

Basuki, K. T., 2000. Diktat Kuliah Kimia Radiasi, BATAN: PATN

Fang H., Hsu S. M., dan Sengers J. V.2003, Ultra-High Molecular Weight Polyethylene Wear Particle Effects on Bioactivity, NIST Special Publication 1002, 
Greer, K. W., King, R. S., dan Chan, F. W., 2003, "The Effects of Raw Material, Irradiation Dose, and Irradiation Source on Crosslinking of UHMWPE," Crosslinked and Thermally Treated Ultra-High Molecular Weight Polyethylene for Joint Replacements, ASTMSTP 1445, S. M. Kurtz, R. Gsell, and J. Martell, Eds., p 209-219, ASTM. International,West Conshohocken, PA,.

John, St., Kenneth. R., dan Poggie, R. A., 2003, "Characterization of the Wear Performance of Crosslinked UHMWPE and Relationship to Molding Procedures," Crosslinked and Thermally Treated Ultra-High Molecular Weight Polyethylene for Joint Replacements, ASTM STP 1445, S. M. Kurtz, R. Gsell, and J. Martell, Eds., p. 220-226, ASTM International, West Conshohocken, PA.

Kim, S , Nho, Y.C., 2009, Controlling of Degradation Effects in Radiation Processing of Polymers, Austria, IAEA Pr.

Lewis, G., 2001, Properties of crosslinked ultrahigh-molecular-weight polyethylene, Biomaterials, 22 ,p 371- 401.

Magda , R., Alexandra, M., dan Herman, M., 2009, Characterization and Accelerated Ageing of UHMWPE Used in Orthopedic Prosthesis by Peroxide, materials ISSN 1996-1944,(2), p. 562-576, Department of Metallurgical and Materials Engineering, Laboratory of Biomaterials and Tissue Engineering

Marsongko, 1997, Pengaruh Radiasi Berkas Elektron pada Sifat Lapisan Campuran uretan akrilat-tripopilen Glikol diakrilat, BATAN, Jakarta.

McKellop, H., Shen, F., Lu, Bin., Campbell, P., and Salovey, R.1999.Development of An Extremely Wear-Resistant Ultra High Molecular Weight Polyethylene For Total Hip Replacements.USA

Retno, W., 2011, Modifikasi Permukaan Polimer UHMWPE DAN HDPE dengan Iradiasi Sinar Gamma untuk Meningkatkan Kekuatan Mekanik Tibial Tray, Skiripsi, Bogor, Dept.Fisika- FMIPA-IPB

Rosario, S.C dan Silva, L.G.A., 2006, Characterization of the virgin and recycled ultra high molecular weight polyethylene irradiated [thesis]. Brazil, Cidade University

Steven, K. M., 2003, The UHMWPE handbook, ultra-high molecular weight polyethylene total joint replacement. Principal
Engineer, Exponent, Inc,Philadelphia, PA.

Sudirman, 1994, Pengaruh Radiasi Netron Cepat pada Sifat Fisik dan Mekanik PE dan Polistiren, BATAN, Jakarta.

Suliwarno A, 1997, Studi Degradasi PP Iradiasi pada Kondisi Lingkungan, Jakarta, BATAN.

Wang S, Ge. S, 2007, The mechanical property and tribological ehaviour of UHMWPE, effect of molding pressure. Wear 263, p, 949-956

Wiwik S, Subono, dan Rahmat, S., 1994, Pengkajian Pelapukan Polimer oleh Cuaca. Puslitbang Fisika Terapan, LIPI, Bandung. 